\title{
Nonformalistic Law in Time and Space
}

\author{
Mark D. Rosen $\dagger$
}

In his provocative contribution to this Symposium, Larry Alexander claims that law's singular function is to coordinate citizens' activities in an expert and efficient manner. ${ }^{1}$ To accomplish this goal, Alexander argues, law must settle controversies and uncertainties by determinately informing citizens what they can and cannot do. ${ }^{2}$ Official edicts that articulate duties at high levels of abstraction, which merely state the law's broad goals, by definition do not "precisely . . . settle the question of what ought to be done." Citizens affected by such edicts and legal decisionmakers charged with applying them accordingly must engage in the difficult task of deciding how the law's statement of its goals meshes with the circumstances at hand. Because they create a need for an interpretive process that is inevitably indeterminate and whose outcomes are invariably controversial, edicts employing abstractions recreate the very uncertainties that law is intended to solve in the first place. ${ }^{4}$ Accordingly, concludes Alexander, to fulfill its purpose, law "must consist of determinate rules" or, in the parlance of this Symposium, it must be "formalistic."

Even assuming as correct the delimited role Alexander ascribes to law, it does not follow that nonformalistic law is a contradiction in terms that has no place in public life. After clarifying what I mean by "formalistic" and "nonformalistic" law, I will discuss two important uses of nonformalistic law, one frequently underappreciated and the second generally overlooked. First, nonformalistic law might be appropriate or necessary in areas of the law where promulgators have a limited ability to lay down detailed rules in advance. Second, nonformality permits nonuni-

$\dagger$ Assistant Professor, Chicago-Kent College of Law. I would like to thank David Charny and Jack L. Goldsmith for exceedingly helpful comments, as well as the suggestions of participants of the Symposium and the editors of The University of Chicago Law Review.

1 Larry Alexander, "With Me, It's All er Nuthin": Formalism in Law and Morality, 66 U Chi I Rev 530, 532-36 (1999). By "efficient" Alexander means minimizing the decisionmaking costs that would otherwise attend the creation of expert rules. Id at 536.

2 Id at 532-36.

3 Id at 533.

- Id at 543 .

5 Id at 530 . 
form applications of law. Although it may seem counterintuitive, nonuniform applications of a single source of law sometimes are a good thing. For example, nonuniformity can help to preserve a single national (or state) culture without unnecessarily destroying local differences. Recognition of these two uses of nonformalistic law suggests that there is no single answer as to whether promulgators of law should enact formalistic or nonformalistic law. The answer instead likely turns on the character of the specific field of law in question.

\section{SOME DEFINITIONS: FORMALISTIC AND NONFORMALISTIC LAW}

For Alexander, formalistic law is interchangeable with the term "rules" as it appears in the familiar "rules-standards" debate. ${ }^{7}$ I use the term "nonformalistic law" synonymously with "standards" as it appears in that literature. "Standards" are laws that describe a triggering event in abstract terms that refer to the ultimate policy or goal animating the law. Thus, when a standard is used, determining what the law proscribes or requires occurs after an individual has acted, at the time the legal decisionmaker determines whether the individual's conduct is or is not consistent with the law's policy or goal. ${ }^{8}$ "Rules," by contrast, are laws that describe the triggering event with factual particulars or other language that is determinate within a community. ${ }^{9}$ Consequently, rules more concretely communicate the content of the law before an individual acts than do standards. ${ }^{10}$ For this reason, only formalistic law at first may appear to be capable of achieving

- See, for example, id at 565 ("The concept of law is bound up with the existence of formal rules."). It might be useful to formally demonstrate the connection between formalistic law and rules in Alexander's thought. Formalism for Alexander refers to "adherence to a norm's prescription without regard to the background reasons the norm is meant to serve." Id at 531. Accordingly, formalism can exist only where there is a possibility of divergence between the prescription and the norm's reason. Rules create that possibility, id at 547-48, whereas standards, which require the legal decisionmaker to consider the norm's background reasons, avoid it. Id at 543. Therefore, for Alexander formalism is bound up with rules, and the concept of formalistic law is interchangeable with rules. Several other participants in this Symposium likewise have treated formalism and "rules" interchangeably. See, for example, David A. Weisbach, Formalism in the Tax Law, 66 U Chi L Rev 860 (1999); Ehud Kamar, Shareholder Litigation Under Indeterminate Corporate Law, 66 U Chi L Rev 887 (1999).

7 See, for example, Louis Kaplow, Rules Versus Standards: An Economic Analysis, 42 Duke L J 557 (1992); Duncan Kennedy, Legal Formality, 2 J Legal Stud 351 (1973); Frederick Schauer, Playing By the Rules 104 n 35 (Clarendon 1991); Roberto Mangabeira Unger, Knowledge and Politics 88-100 (Free Press 1975).

- See Kaplow, 42 Duke I J at 560 (cited in note 7).

- See Alexander, 66 U Chi L Rev at 544 (cited in note 1).

${ }^{10}$ See Kaplow, 42 Duke $L J$ at 560 (cited in note 7). 
the aim that Alexander attributes to law-determinately informing citizens of their duties.

\section{NONFORMALISTIC LAW IN TIME: INVITING ONGOING CREATION}

As has been recognized by others, ${ }^{11}$ nonformalistic law might be appropriate or necessary in areas of the law where the promulgators of law have a limited ability to lay down detailed rules in advance. In such circumstances, the best that can be done may be to identify the overarching policy goals in the form of standards. When faced with standards, courts (or agencies, ${ }^{12}$ as the case may be) typically seek to develop legal tests that, by their very nature, particularize the proscribed or required conduct and thereby make the law more rule-like. ${ }^{13}$ Employing nonformalistic law in the form of broad standards thus can be conceptualized as an invitation to courts to participate actively and consciously in the law's ongoing development.

Consider antitrust law in this regard. The prohibitions found in the core antitrust statutes for the most part eschew formalistic expression; they essentially state policy goals and delegate the development of formalistic rules to the courts. ${ }^{14}$ For example, the Sherman Act makes unlawful every "contract, combination ... or conspiracy, in restraint of trade"15 and conduct to "monopolize, or attempt to monopolize . . . any part of . . . trade."16 This central statutory provision thus does not identify concretely what actions

\footnotetext{
"See, for example, Cass R. Sunstein, Foreword: Leaving Things Undecided, 110 Harv L Rev 6, 42 (1996).

12 Like courts, agencies also frequently are called on to "specify standards." Cass $R$. Sunstein, Is Tobacco a Drug? Administrative Agencies as Common Law Courts, 47 Duke I $\mathrm{J} 1013,1019$ (1998). For the rest of this Comment, however, I will simply refer to courts and ask the reader to keep in mind that the arguments apply to agencies as well.

13 For this point, see Larry Alexander, Constrained by Precedent, $63 \mathrm{~S}$ Cal L Rev 3, 17 19 (1989) (describing the "rule model of precedent" in which courts use the facts of a case to promulgate a more general rule); Kaplow, 42 Duke L J at 611 (cited in note 7) (noting that precedent can "transform[ ] standards into rules").

${ }^{14}$ This is recognized by virtually all antitrust scholars. See, for example, Phillip Areeda and Louis Kaplow, Antitrust Analysis: Problems, Text, Cases 5-6 (Little, Brown 4th ed 1988) (noting that "the [Sherman] Act may be little more than a legislative command that the judiciary develop a common law of antitrust"); William F. Baxter, Separation of Powers, Prosecutorial Discretion, and the "Common Law" Nature of Antitrust Law, 60 Tex L Rev 661, 663 (1982) (arguing that in antitrust "Congress in effect delegated much of its lawmaking power to the judicial branch"); Frank H. Easterbrook, Is There a Ratchet in Antitrust Law?, 60 Tex L Rev 705, 706 (1982) (arguing that the antitrust statutes "authorized the Supreme Court to invent and enforce a law of restraint of trade in the common law fashion").
}

is 15 USC \& 1 (1994).

1s 15 USC \& 2 (1994). 
are impermissible, but instead describes the prohibited acts in highly abstract terms that restate the statute's ultimate policy goals. ${ }^{17}$ The fact that a few provisions of the antitrust statutes do employ formalistic rules ${ }^{18}$ underscores the significance of Congress's decision to adopt, for the most part, nonformalistic antitrust law, for it establishes that Congress knew how to draft formalistic rules when it wanted to.

But why did Congress elect to rely predominantly on broad standards in this field of law? A plausible answer is that Congress did not perceive itself as being capable of providing effective detailed rules because it had "little understanding of what the government could and ought to do to" achieve antitrust's policy goals. ${ }^{19}$ Congress well could have believed that courts, by contrast, could function as "great laboratories of the law" where "[e]very new case is an experiment" such that "if the accepted rule which seems applicable yields a result which is felt to be unjust, the rule [can be] reconsidered." ${ }^{20}$

This raises an empirical question that has not been fully appreciated by some commentators in the rules-standards debate: ${ }^{21}$ Is it possible that sometimes legislatures do not, and cannot, have the information necessary to enact formalistic law? Stated differently: Is it possible that legislative enactment is not always a substitute for common law methodology? My guess is that the answer is in the affirmative-that there are some bodies of law that implicate such socially complex phenomena that only case-bycase problem solving will work, at least at the start. And antitrust may be one such field of law.

The challenge, of course, is to identify the characteristics of bodies of law that are particularly unsuited to ex ante formalization. Perhaps the suitable candidates are those areas of law that are shaped by fields of social science that are not adequately developed to serve as reliable frameworks for developing detailed rules. Perhaps the candidate fields involve particularly complex

17 The same can be said for Section 7 of the Clayton Act, 15 USC $\S 18$ (1994), which provides that "no person ... shall acquire ... any part of the stock or . . . assets of another person ... [where] the effect . . . may be substantially to lessen competition, or to tend to create a monopoly."

${ }^{18}$ See, for example, 15 USC $\$ 19$ (1994) (rules prohibiting interlocking directorates).

19 Baxter, 60 Tex L Rev at 666 (cited in note 14).

${ }^{20}$ Id at 665, quoting Munroe Smith, Jurisprudence 21 (Columbia 1909), quoted in Benjamin N. Cardozo, The Nature of the Judicial Process 23 (Yale 1921).

${ }^{21}$ See Kaplow, 42 Duke L J at 568, 599-602 (cited in note 7) (assuming that law promulgators can decide whether or not to invest ex ante the time to acquire the information that will enable them to create rules and identifying only two circumstances under which it is not possible to promulgate rules in advance). 
interplays of competing principles and commitments, and perhaps we as a society, as an epistemological matter, distrust efforts to resolve such conflicts at highly abstract levels and instead favor case-by-case solutions that, by their nature, allow for particularized decisionmaking grounded in experience and empirical facts. Perhaps the candidate doctrinal fields concern matters in which social norms are rapidly changing (possibly induced by the law itself $\mathrm{f}^{22}$, requiring continuous reformulation of the doctrine so it is maximally responsive to the changing nature of the subjects being regulated. ${ }^{23}$

Indeed, it may even be the case that some fields of law may never be amenable to formalism. ${ }^{24}$ Formalistic law by its nature is highly reductivist-seeking to isolate as legally determinative a limited number of facts from the infinitude of facts that characterizes any given circumstance-and the costs of reductivism might be unacceptably high in some situations due to the high number of factors that fairness and other considerations suggest are legally relevant. Antitrust may be instructive in this regard, as well. Although there are many rule-like antitrust doctrines, it is striking that, after more than a century of antitrust litigation, the rule of reason-a nonformalistic doctrine that bids the legal decisionmaker to make highly case-specific determinations ${ }^{25}$ remains among the foremost antitrust doctrines. ${ }^{26}$

To return to Alexander's analytical framework, it surely is possible that, at least with respect to some fields of law, step-bystep formalization of broad standards is necessary to create expert rules. ${ }^{27}$ Conversely, the hasty promulgation of rules in fields not amenable to ex ante formalization may well create not only

${ }^{2}$ See Cass R. Sunstein, On the Expressive Function of Law, $144 \mathrm{U} \mathrm{Pa} \mathrm{L}$ Rev 2021 (1996) (examining how law effectuates changes in social norms).

${ }^{2}$ See William N. Eskridge, Jr., Dynamic Statutory Interpretation 124-26 (Harvard 1994) (arguing that statutes' interpretations can be altered over time so that the statutes' directives can be adapted to changed circumstances).

${ }^{24}$ See Kaplow, 42 Duke L $J$ at 599-602 (cited in note 7) (noting circumstances under which it may be difficult to formulate law as rules).

${ }^{25}$ See Philip C. Zerrillo, Jon M. Flemming, and Angela McKee, Vertical Territory and Customary Resale Restrictions: A New Rule of Reason Approach, $22 \mathrm{~J}$ Corp L 705, 709-10 (1997) ("A rule of reason standard is necessary because business conditions change. The standard is an adaptive approach to analyzing changing business practices. It is flexible enough to conform to evolving economic theory about why different businesses use different tactics.").

${ }^{26}$ See Ernest Gellhorn and Teresa Tatham, Making Sense Out of the Rule of Reason, 35 Case W Res L Rev 155, 156 (1985) (noting the large and growing role of rule of reason analysis); Continental T.V., Inc v GTE Sylvania Inc, 433 US 36, $57-59$ (1977) (overruling an earlier case that held nonprice vertical restraints to be per se illegal and adopting a rule of reason analysis).

${ }^{n}$ See Alexander, 66 U Chi L Rev at 539-40 (cited in note 1). 
maladroit doctrines but also Alexanderian inefficiencies insofar as premature codification increases the time and other resources that must be spent to arrive ultimately at expert rules. ${ }^{28}$ For these reasons, Alexander might well agree that initially deploying nonformalistic law in such fields of law is acceptable, if not desirable. ${ }^{29}$

In the end, I cannot here hope to show that Congress decided correctly when it elected to enact the bulk of antitrust law in a nonformalistic fashion. ${ }^{30}$ It is sufficient for present purposes, however, to show that a connection exists between nonformalistic law and the ongoing development of law in fields that are difficult to codify in advance (or, perhaps, that are difficult to codify at all). Furthermore, understanding that nonformalistic law can serve as an invitation to courts to develop the law yields another useful insight. Except in those fields of law that are not amenable to being expressed as rules, deciding whether law should be formalistic or not may turn only on timing: Should (or can) the law be made formalistic from the start, or should we sometimes allow courts to make it formalistic over time?

\section{NONFORMALISTIC LAW IN SPACE: FACIIITATING GEOGRAPHICAL NONUNIFORMITY}

Nonformalistic law can be a tool to permit nonuniform applications of law. Nonformalistic law, by its nature, vests discretion in the legal decisionmaker, and discretion naturally invites varia-

\footnotetext{
${ }^{28}$ See id at 536 (discussing the value of reducing decisionmaking costs). There are many such possible costs of premature codification. One source, for example, is the costs involved in the legislature's redrafting of the law, as well as the subsequent costs of amendment that must be absorbed until the legislature is in a position to identify the expert rules. A second cost is that premature codification potentially can delay, if not altogether prevent, critics and formulators of law from being capable of even identifying the expert xules on account of the channeling of thought and imagination that may result from the initial premature codification. For an exploration of this type of cost in a parallel context, see Mark D. Rosen, What Has Happened to the Common Law?-Recent American Codifications, and Their Impact on Judicial Practice and the Law's Subsequent Development, 1994 Wis L Rev 1119, 1217-52 (examining how codifying the common law limited the universe of perceived legal options).

2 Here I assume that Alexander's conception of law is consequentialist, see, for example, Alexander, $66 \mathrm{U}$ Chi L Rev at 562 (cited in note 1) ("the moral benefits of serious rules are consequentialist in character"); id at 530 ("[L]aw may turn out to be a moral possibility only for consequentialists."), and that Alexander accordingly would be amenable to suggestions that deploying nonformalistic law in certain circumstances can be consequentially justified in respect of the very goals he ascribes to law.

${ }^{30}$ Consistent with the case law, my analysis assumes that there are virtually no ruleof-law due process requirements in respect of formality outside of the contexts of speech and criminal law. See Boutilier v INS, 387 US 118, 123 (1967) (civil statute void for vagueness only if it is "so vague and indefinite as really to be no rule or standard at all"), citing A B Small Co v American Sugar Refining Co, 267 US 233, 239 (1925).
} 
tions in application. ${ }^{31}$ Nonformalistic law thus permits a middle course between chaos and homogeneity: nonformalistic law can articulate a set of policy goals that are sufficiently concrete so as to provide the uniformity needed to create a single political culture at a broad (let us say federal) level while permitting differential applications of the goals at local levels where discrete political communities exist whose distinctiveness society believes it desirable to maintain. Indeed, coordinating a nation's citizens without snuffing out heterogeneity at subfederal levels can be normatively attractive in so large and diverse a country as ours (although I will not defend this proposition here). What I would like to do is to illustrate the connection of nonformalistic law to geography-based nonuniformity by examining two contemporary federal statutes, the Indian Civil Rights Act and the Bankruptcy Code.

\section{A. The Indian Civil Rights Act}

Nonformalistic law has allowed for the creation of nonuniform applications of the Indian Civil Rights Act ("TCRA") ${ }^{32}$ that have been instrumental in maintaining the integrity of tribal political communities. Because most federal constitutional provisions do not apply to tribal governments, ${ }^{33}$ Congress in the ICRA imposed statutory obligations on tribal governments that almost track verbatim the broad standards found in the Bill of Rights. ${ }^{34}$ For example, the ICRA bars a tribe from making or enforcing laws "prohibiting the free exercise of religion, or abridging the freedom of speech" or "deny[ing] to any person within its jurisdiction the equal protection of its laws or depriv[ing] any person of liberty or property without due process of law."35

But what do broad standards such as "due process" and "equal protection" require of the tribes concretely? Not the same thing that these standards have been held to require of federal, state, and local governments. This is because each tribe's tribal

\footnotetext{
${ }^{31}$ Whether the variation survives, of course, turns on the practices of reviewing appellate courts.

${ }^{32} 25$ USC $\$ \S 1301-41$ (1994).

* See Talton $v$ Mayes, 163 US 376 (1896) (holding that the Fifth Amendment does not apply to the Cherokee nation); Native American Church of North America $v$ Navajo Tribal Council, 272 F2d 131, 134-35 (10th Cir 1959) (holding that the First Amendment is inapplicable to tribal governments). See generally William C. Canby, Jr., American Indian Law in a Nutshell 28-29, 241-44 (West 1988) (noting traditional inapplicability of the Constitution to tribal governments).

${ }^{34}$ See Santa Clara Pueblo v Martinez, 436 US 49, 63 (1978) (noting that most but not all of the Bill of Rights provisions were applied against tribes statutorily in the ICRA).

3s 25 USC \& 1302 (1994).
} 
courts are permitted to construe the ICRA's broad standards in light of the tribe's values and needs, with virtually no federal court review. ${ }^{36}$ As a result, the federal law of free speech and jury rights, for example, differs not only between general society and Indian country ${ }^{37}$ but among the different Indian tribes as well. So, for example, contrary to what federal law requires in non-Indian polities, it has been held that "freedom of speech" is not impaired by legislation that prohibits members of the Grand Ronde tribal council from using vulgarities in public. ${ }^{38}$ To provide another example, contrary to Sixth and Seventh Amendment jurisprudence, the jury right in Navajo reservations includes nonlitigants' rights to participate in self-government by serving on juries. ${ }^{39}$

Is there a rationale to such a system of nonuniform construction of a federal law? I think so. ${ }^{40}$ The ICRA forces tribes to absorb basic Anglo constitutional commitments, thereby bringing them within the fold of the greater American political culture, but permits the tribes to express them in ways that reflect tribal values and permit each tribe's distinctive political community to endure. ${ }^{41}$ Thus, nonformalistic law has permitted coordination without commanding homogenization.

Furthermore, the use of nonformalistic law at the "higher" federal level in the ICRA does not mean that the law remains nonformalistic at the "Iower" level of each tribal court. In fact,

${ }^{36}$ Virtually all ICRA claims are litigated in tribal courts because federal courts have only limited subject matter jurisdiction. Furthermore, the ICRA provisions need not be construed in the way that federal courts have interpreted the ICRA's sister terms in the federal Constitution. For a full explanation of this legal regime, see Mark D. Rosen, Our Nonuniform Constitution: Geographical Variations of Constitutional Requirements in the Aid of Community, 77 Tex L Rev 1129, 1139-41 (1999).

$"$ "Indian country" is a statutory term denoting places of tribal jurisdiction. See 18 USC § 1151 (1994).

${ }^{3}$ See Brandon $v$ Tribal Council for the Confederated Tribes of the Grand Ronde Community of Oregon, 18 Indian L Rep 6139, 6141 (Grand Ronde Tr Ct 1991).

3" See Downey v Bigman, 22 Indian L Rep 6145, 6146 (Nav Sup Ct 1995) ("TT]he fundamental right to a jury trial in civil cases complements and enhances the traditional doctrine of Navajo participatory democracy."). See also Rosen, 77 Tex L Rev at 1145-46 \& n 80 (cited in note 36) (explaining differences between the Navajo understanding of jury rights, which includes a self-governance rationale, and the ordinary federal understanding, which is primarily to protect the accused).

${ }^{*}$ To note that there is a rationale is not to say that I agree with it. Elsewhere I have criticized the ICRA for unnecessarily interfering with tribal autonomy, see Mark D. Rosen, The Outer Limits of Community Self-Governance in Residential Associations, Municipalities, and Indian Country: A Liberal Theory, $84 \mathrm{Va}$ L Rev 1053, 1136 (1998), and I continue to believe that the ICRA is justified only insofar as it is necessary to ensure that the conditions of "well-orderedness" and "exit" are met. See id at 1093-1106.

${ }^{12}$ See Rosen, 77 Tex L Rev at 1156-58 (cited in note 36); Mark D. Rosen, Uncommonly Decentralized Interpretation of Federal Law 21-29 (unpublished manuscript on file with U Chi L Rev). 
each tribe generally formalizes the ICRA's standards. ${ }^{42}$ At the same time, the fact that the law ultimately is formalized does not mean that enacting nonformalistic law at the higher federal level was pointless in the first place. After all, by deploying nonformalistic law in this manner, the distinctive political community of each tribe was enabled to formulate a unique formalization that best suited its needs and values. ${ }^{43}$

\section{B. The Bankruptcy Code}

Doctrinal nonuniformity as a result of nonformalistic law is not limited to the highly idiosyncratic field of Native American law. Bankruptcy scholars for some time have observed that, notwithstanding the fact that the Bankruptcy Code is federal law, there is a "coherent and persistent variation in the application of" bankruptcy law from locale to locale. ${ }^{44}$ What they have found is "not mere inconsistency in the application of a uniform law" but that

there are coherent and predictable inconsistencies or variations from one locality to another, that these variations persist over long periods of time despite major shifts in formal law and economic conditions, and that the origin of these variations is a culture governing the behavior of actors in the bankruptcy system in each locality. ${ }^{45}$

For example, one study has shown that across locales there are marked differences in the per capita rates of bankruptcy filings that cannot be explained by economic or demographic variables. ${ }^{46}$ Similarly, two studies have shown statistically significant differences across locales in the percentages of debtors that

${ }^{4}$ See Rosen, Uncommonly Decentralized at 37-53 (cited in note 41) (reviewing all reported tribal court decisions construing the ICRA over a ten-year period).

${ }^{4}$ Of course, tribes also can reformulate the formalizations as changing needs and tribal values might require.

4 Jay L. Westbrook, Local Legal Culture and the Fear of Abuse, 6 Am Bankr Inst I Rev 25, 25 (1998). See also Jean Braucher, Lawyers and Consumer Bankruptcy: One Code, Many Cultures, 67 Am Bankr L J 501, 503 (1993) (concluding that "local administrative practices and legal culture have more effect on choices in consumer bankruptcy than do features of the law conventionally thought to be important to chapter choice"); Teresa A. Sullivan, Elizabeth Warren, and Jay Lawrence Westbrook, The Persistence of Local Legal Culture: Twenty Years of Evidence From the Federal Bankruptcy Courts, 17 Harv J L \& Pub Pol 801, 807-12 (1994) (conducting a study of the effect of local legal cultures on the outcome of bankruptcy cases).

45 Westbrook, 6 Am Bankr Inst L Rev at 26-27 (cited in note 44).

4s Sullivan, Warren, and Westbrook, 17 Harv J L \& Pub Pol at 817-22, 833-39 (cited in note 44). 
choose Chapter 7 rather than Chapter 13 proceedings. ${ }^{47}$ Another study has demonstrated significant differences among judicial districts in the percentages of payment that are promised in Chapter 13 plans. ${ }^{48}$

One might ask: How can there be such variation when there is a single federal bankruptcy statute? Nonformalistic law in the Bankruptcy Code is an important part of the answer. ${ }^{49}$ Nonuniformity across locales has been attributed inter alia to the presence of standards in key parts of the Bankruptcy Code because the standards have been interpreted differently across jurisdictions..$^{50}$ For instance, the predominate gatekeeping provision to Chapter 7 is a broad standard that gives courts the power to dismiss Chapter 7 filings in cases of "substantial abuse."51 This standard has been construed in considerably different ways across jurisdictions, with some courts finding substantial abuse where a debtor has the ability to pay a significant portion of her debts under a Chapter 13 plan. ${ }^{52}$ Similarly, debt repayment required in Chapter 13 is determined on the basis of disposable income that is available after "reasonably necessary expenses," another broad standard that has invited substantially varying constructions. ${ }^{53}$

\footnotetext{
${ }^{47}$ Id at 828-30; Braucher, $67 \mathrm{Am}$ Bankr L J at 502-04 (cited in note 44). Chapter 7 is generally regarded as providing the debtor a fresh start, discharging most of his debts but requiring him to give up nonexempt property, see 11 USC $\S \S 721-28$ (1994), whereas Chapter 13 requires that the bankrupt propose a plan for full or partial repayment of debts out of post-filing income, see 11 USC $\S \S 1321-30$ (1994). In reality, however, the options between the two chapters are more subtle because Chapter 7 can involve debt repayment and Chapter 13 can require only small amounts of debt repayment. See generally Jean Braucher, Increasing Uniformity in Consumer Bankruptcy: Means Testing as a Distraction and the National Bankruptcy Review Commission's Proposals as a Starting Point, 6 Am Bankr Inst L Rev 1, 12-13 (1998) (discussing the differences between filing under Chapter 7 and Chapter 13).

${ }^{*}$ William C. Whitford, The Ideal of Individualized Justice: Consumer Bankruptcy as Consumer Protection, and Consumer Protection in Consumer Bankruptcy, 68 Am Bankr I J 397, 409-12 (1994).

49 Another important component is that the Bankruptcy Code permits states to opt out of select provisions and substitute their own. See Braucher, $6 \mathrm{Am}$ Bankr Inst L Rev at 15 (cited in note 47) ("The incorporation of state law into federal bankruptcy law ... builds in nonuniformity.").

${ }^{\text {so }}$ See id at 15-16.

s1 11 USC $\S 707(b)$ (1994).

${ }^{32}$ Compare In re Kelley, 841 F2d 908, 915 (9th Cir 1988) (dismissing Chapter 7 filing where debts could be paid to creditors), with In re Green, 934 F2d 568, 572 (4th Cir 1991) (finding that the court must look at the totality of the circumstances in deciding whether to dismiss a Chapter 7 filing). See generally Wayne R. Wells, Janell M. Kurtz, and Robert J. Calhoun, The Implementation of Bankruptcy Code Section 707(b): The Law and the Reality, 39 Cleve St L Rev 15, 28-35 (1991).

ss See Braucher, $6 \mathrm{Am}$ Bankr Inst L Rev at 16 (cited in note 47).
} 
Is such nonuniformity desirable ${ }^{54}$ Commentators to date have offered varying responses. ${ }^{55}$ While I cannot here address the range of questions that must be asked to determine whether this type of nonuniformity in bankruptcy is good, it seems to me that a reflexive conclusion that it is problematic is unwarranted. Nonuniformity is not tantamount to chaos; the Bankruptcy Code has decided the broad policy questions but allows variations at the margins in areas where people are deeply divided. ${ }^{56}$ Further, it is important to note that the nonuniformity that bankruptcy scholars have observed is not random. Instead, there are consistent variations across localities. This suggests that the nonuniformity correlates to differing perspectives held by different geographybased communities, which in turn implies that analyzing the desirability of uniformity entails inter alia a normative assessment concerning the value of opting for a single national norm at the expense of maintaining different local cultures. ${ }^{57}$

The example of bankruptcy law provides two important lessons that parallel those learned from the ICRA concerning nonformalistic law. First, bankruptcy illustrates once again the link between nonformalistic law and nonuniformity. Second, the fact that the nonuniformity generated by the Bankruptcy Code's nonformalistic provisions is not random suggests that there are

\footnotetext{
st Indeed, the question can be sharpened: Is such nonuniformity constitutional in light of Article I's grant to Congress of the power to establish "uniform Laws on the subject of Bankruptcies throughout the United States"? US Const, Art I, § 8 (emphasis added). To date, commentators have not suggested that the nonuniformities in bankruptcy are unconstitutional, and I cannot explore this issue more fully here. In any event, the discussion in the text above may be instructive in identifying what Article I's language regarding "uniform Laws" requires.

ss Compare National Bankruptcy Review Commission, Bankruptcy: The Next Twenty Years 81, 235 (GPO 1997) (nonuniformity of exemptions is problematic), with Sullivan, Warren, and Westbrook, 17 Harv J L \& Pub Pol at 858-59 (cited in note 44) (contemplating the "role local resitance and adaptation of national laws play in permitting a large, diverse society to be governed from a central position"); Westbrook, 6 Am Bankr Inst L Rev at 25-26 (cited in note 44) (nonuniformity is inevitable).

${ }^{36}$ Compare Braucher, $67 \mathrm{Am}$ Bankr $\mathrm{L} J$ at 560 (cited in note 44) (noting the view of one bankruptcy trustee that "Chapter 13 isn't for everybody. A person with a young family needs a fresh start, to take a bath, and rebuild from that. There's a duty to the familynot to repay debts for five years [under chapter 13]"), with id at 558 (noting San Antonio, Texas lawyers' views that encouraging Chapter 13 bankruptcies is a "moral issue" because "creditors should be paid").

57 Although I cannot pursue this in full here, in my view, the question of whether geographical nonuniformities violate the rule of law's principle that like cases be decided identically also turns on the normative assessment of whether varying local cultures should be maintained. If so, then the mere fact that cases arise in different localities makes them sufficiently different to merit differential treatment. Under this view, people who locate themselves in a particular geographical area in effect consent to being governed by local norms. The community standards doctrine in the First Amendment perhaps can best be understood in this way. See Rosen, 77 Tex I Rev at 1149-52 (cited in note 36).
} 
mechanisms that help to formalize the decisionmaking at the local levels. In other words, the question may not be so much whether to have formalistic or nonformalistic law but whether we can tolerate nonformalistic law at the "higher" (let us say federal) levels with the understanding that there likely will be formalization that occurs at the "lower" levels, albeit formalizations that very well may differ from each other.

Finally, it is instructive to try to understand precisely why the conception of law Alexander formulates in his contribution to this Symposium does not accommodate the nonformalistic law, and the resulting geographical nonuniformity, found in the ICRA and the Bankruptcy Code. The answer, I believe, is that Alexander's analysis implicitly assumes the existence of a single nationwide community, for it is against such a singular community that he hypothesizes the law must provide a singular determinate rule. ${ }^{58}$ But as the ICRA and the Bankruptcy Code suggest, this assumption of a single national community is not axiomatic. Indeed, whether we as a society should presume a single national community that requires lockstep legal uniformity in all legal matters is a question about which people likely would disagree. Here I intend not to argue on behalf of either side of the controversy, but simply to expose the contested proposition and point out that there is yet another notable contemporary use for nonformalistic law if we as a society should agree that, at least sometimes, a normatively desirable level of uniformity can be attained by broad standards that are differentially formalized across diverse subfederal political communities. Lastly, it is worth noting that Alexander himself might agree with this proposition because, as best as I can tell, there is nothing intrinsic to his jurisprudence that mandates the assumption of a single nation-wide community.

\section{CONCLUSION}

Notwithstanding Alexander's forceful arguments on behalf of formalistic law, it would be a mistake to conclude that there is no contemporary role for nonformalistic law. Indeed, nonformalistic law may be important early in the life of select statutes and at "higher" levels of government for some fields of law. Because courts ordinarily transform standards into rule-like formalizations over time, the legislature's deployment of standards generally serves to delegate rulemaking authority to courts. Nonfor-

\footnotetext{
${ }^{53}$ Alexander, $66 \mathrm{U}$ Chi L Rev at 531-36 (cited in note 1).
} 
malistic law can be beneficial when legislatures are not capable of laying down highly formalized rules at the time of enactment. Nonformalistic law also can be useful when legislatures want to decide certain broad policy questions but think it wise to allow differential applications of the principles at local levels. For these reasons, it likely is the case that there is no single answer as to whether legislatures should employ formalistic or nonformalistic law. The answer instead likely varies from field of law to field of law. 


\section{SYMPOSIUM: FORMALISM REVISITED}

\section{FORMALISM AND STATUTORY INTERPRETATION}

Must Formalism Be

Defended Empirically? .............................Cass R. Sunstein 636

Norms, Empiricism, and Canons

in Statutory Interpretation ............ William N. Eskridge, Jr. 671

Constitutional Structure and

Statutory Formalism..............................John F. Manning 685

Interpretation, Empiricism, and

the Closure Problem................................Adrian Vermeule 698

Moderated by Elizabeth Garrett 